\title{
KEMAMPUAN PEMECAHAN MASALAH MATEMATIKA MELALUI BEBERAPA MODEL PEMBELAJARAN
}

\author{
Eliezer Sembiring \\ Prodi Pendidikan Matematika \\ Universitas Negeri Medan, Jalan Willem Iskandar, Pasar V, Medan 20221, Indonesia \\ E-mail: eliezersembiring@mhs.unimed.ac.id
}

\begin{abstract}
Abstrak
Penelitian ini bertujuan untuk mengetahui beberapa model pembelajaran yang dapat mempengaruhi kemampuan pemecahan masalah matematika. Jenis penelitian yang digunakan adalah meta analisis dari penelitian yang telah dilakukan sebelumnya. Penelitian ini menggunakan metode sintesis kuantitatif. Penelitian ini mengulik beberapa jurnal mengenai model pembelajaran dalam meningkatkan ataupun mempengaruhi kemampuan pemecahan masalah matematika siswa. Pengumpulan data dalam penelitian ini dilakukan dengan menelusuri jurnal melalui Google Cendekia. Kata kunci yang digunakan untuk penelusuran jurnal adalah: kemampuan pemecahan masalah, model. Dari beberapa jurnal kemampuan pemecahan masalah dipilih hasil penelitian untuk dianalisis lebih lanjut. Berdasarkan hasil analisis dari tiga model pembelajaran dapat disimpulkan bahwa dengan penerapan model pada masing-masing jurnal dapat diketahui bahwa terjadi peningkatkan kemampuan pemecahan masalah matematika yang ditandai dari peningkatan hasil belajar siswa.
\end{abstract}

Kata kunci: kemampuan pemecahan masalah , model

\begin{abstract}
This study aims to find out several learning models that can affect the ability to solve mathematical problems. This type of research is a meta-analysis of research that has been done before. This research uses quantitative synthesis method. This research examines several journals about learning models in improving or influencing students' mathematical problem solving abilities. Data collection in this research was carried out by searching journals through Google Scholar. The keywords used for journal search are: problem solving skills, models. From a number of journals, the problem solving ability was chosen as the research results for further analysis. Based on the results of the analysis of the three learning models it can be concluded that by applying the model to each journal it can be seen that there is an increase in the ability to solve mathematical problems marked by an increase in student learning outcomes.
\end{abstract}

Keywords: problem solving ability, model

\section{PENDAHULUAN}

Pendidikan adalah proses meningkatkan kualitas manusia baik dari segi pengetahuan, sikap, dan keterampilan dengan mengikuti prosedur tertentu agar dapat bermanfaat bagi dirinya, keluarga, masyarakat, bangsa, dan negara. Jadi pendidikan tidak hanya mengembangkan kemampuan intelektual saja namun juga bagaimana mengimplementasikannya dalam kehidupan bermasyarakat dengan menanamkan nilainilai moral. (Pehkonen, 2007). Pendidikan merupakan proses interaksi antara peserta didik dan tenaga pendidik dalam kegiatan pembelajaran. Guru sebagai tenaga pendidik berperan penting dalam memberikan pengetahuan kepada peserta didik sehingga 
memiliki penguasaan pengetahuan dan keterampilan hidup yang dibutuhkan dalam menghadapi kehidupan nyata. Guru memiliki kewajiban untuk melahirkan generasi muda yang berkualitas baik dari segi intelektual maupun dari segi moralnya. Hal ini dapat dilakukan dengan menciptakan pembelajaran yang efektif. Dalam kegiatan pembelajaran terjadi interaksi guru dengan siswa, maupun interaksi siswa dengan sumber belajar. (Abubakar, 2015).

Pembelajaran matematika adalah suatu proses berpikir disertai dengan aktivitas fisik dan afektif. Menurut Piaget (dalam Hajidin, 2016) matematika tidak diterima secara pasif, matematika dibentuk dan ditemukan oleh siswa secara aktif. Pengetahuan yang diterima siswa secara pasif menjadikan matematika itu tidak bermakna bagi siswa. Matematika sebaiknya dikonstruksi oleh siswa bukan diterima dalam bentuk jadi.

Pemecahan masalah merupakan proses menerapkan pengetahuan yang telah diperoleh sebelumnya pada situasi baru dan berbeda. Selain itu NCTM juga mengungkapkan tujuan pengajaran pemecahan masalah secara umum adalah untuk (1) membangun pengetahuan matematika baru, (2) memecahkan masalah yang muncul dalam matematika dan di dalam konteks-konteks lainnya, (3) menerapkan dan menyesuaikan bermacam strategi yang sesuai untuk memecahkan permasalahan dan (4) memantau dan merefleksikan proses dari pemecahan masalah matematika. (NCTM, 2016). Pemecahan masalah merupakan kemampuan dasar yang harus dimiliki oleh siswa. Kemampuan pemecahan masalah menjadi salah satu kompetensi yang harus di kembangkan siswa pada materi-materi tertentu. (Montague, 2007)

Rendahnya kemampuan pemecahan masalah matematika siswa disekolah dari apa yang diamati peneliti jika dilihat dari jalur modus penyampaian pesan pembelajaran, penyelenggaraan pembelajaran lebih sering menggunakan modus telling (pemberian informasi), ketimbang modus demonstrating (memperagakan) dan doing direct performance (memberikan kesempatan untuk menampilkan hasil kerja secara langsung). Hal ini menunjukan proses belajar mengajar lebih berpusat pada guru sehingga pembelajaran yang dilakukan oleh guru kurang menarik, monoton dan terasa membosankan. Kata lain pada proses pembelajaran masih banyak guru yang mengikuti pola pembelajaran konvensional, yaitu guru menjelaskan materi pelajaran, memberikan contoh-contoh, dan selanjutnya siswa melakukan latihan-latihan. Metode mengajar yang digunakan diantaranya ceramah, tanya jawab, pemberian tugas dan kerja kelompok. Dengan demikian, strategi yang digunakan guru dalam pembelajaran kurang tepat. (Surya,2017).

Pada kenyataannya proses pembelajaran yang dilakukan guru masih belum berjalan secara maksimal khususnya pada mata pelajaran matematika. Matematika merupakan salah satu mata pelajaran yang dianggap sulit oleh peserta didik. Salah satu penyebabnya adalah cara guru mengajar yang masih konvensional dengan ceramah, menjelaskan materi di depan kelas, dan melakukan tanya jawab dengan peserta didik yang bisa atau aktif di dalam kelas. Hal ini membuat proses pembelajaran didominasi oleh guru dan beberapa peserta didik saja. Sedangkan bagi peserta didik yang pasif, tidak memiliki banyak peran dalam proses pembelajaran. (Dwi, 2013). Matematika menjadi salah satu mata pelajaran yang dianggap sulit karena capaian hasil belajar peserta didik masih kurang. Kunci dalam pembelajaran matematika adalah pemahaman konsep yang baik. Untuk mendalami sebuah konsep baru, peserta didik terlebih dahulu memahami konsep pada materi sebelumnya. Hal ini merupakan syarat bagi peserta didik agar dapat menerima dan memahami konsep baru dengan mudah. (Becerra, 2012).

Problem solving matematika adalah suatu cara untuk menyelesaikan masalah matematika dengan menggunakan penalaran matematika (konsep matematika) yang telah dikuasai sebelumnya. Problem solving melibatkan konteks yang bervariasi yang berasal dari penghubungan masalah-masalah dalam kehidupan sehari-hari untuk situasi matematika yang ditimbulkan. (NCTM, 2000). Problem solving adalah komponen penting untuk belajar matematika dimasa sekarang. Dengan problem solving, siswa akan 
mempunyai kemampuan dasar yang bermakna lebih, dari sekadar kemampuan berpikir, dan dapat membuat strategi-strategi penyelesaian untuk masalah-masalah selanjutnya. Surya (dalam Pardede, 2017) menyatakan bahwa problem solving atau pemecahan masalah matematika merupakan jantungnya matematika. Siswa yang mampu memecahkan masalah matematika lebih mudah memahami dan menyelesaikan permasalahan matematika dan masalah kehidupan sehari-hari. Hal yang menyebabkan rendahnya kemampuan pemecahan masalah siswa adalah model pembelajaran yang kurang cocok yang digunakan oleh guru untuk dapat menggali kemampuan penalaran pada diri siswa. (Surya,2017).

Seorang siswa dikatakan memiliki kemampuan pemecahan masalah dalam pembelajaran matematika ketika siswa mencapai kriteria-kriteria tertentu atau biasa dikenal dengan indikator. Ada empat indikator pemecahan masalah matematika menurut Polya (dalam Panjaitan dan Sri, 2017) Understanding the problem (memahami masalah), yaitu mampu membuat apa (data) yang diketahui, apa yang tidak diketahui (ditanyakan), apakah informasi cukup, kondisi (syarat) apa yang harus dipenuhi, dan menyatakan kembali masalah asli dalam bentuk yang lebih operasional (dapat dipecahkan), 2) Devising a plan (merencanakan penyelesaian), yaitu dengan mencoba mencari atau mengingat masalah yang pernah diselesaikan yang memiliki kemiripan dengan masalah yang akan dipecahkan, mencari pola atau aturan, dan menyusun prosedur penyelesaian (membuat konjektur), 3) Carrying out the plan (melaksanakan rencana), yaitu menjalankan prosedur yang telah dibuat untuk mendapatkan penyelesaian, dan 4) Looking back (melihat kembali), memeriksa bagaimana hasil itu diperoleh, memeriksa sanggahannya, mencari hasil itu dengan cara yang lain, melihat apakah hasilnya dapat dilihat dengan sekilas dan memeriksa apakah hasil atau cara itu dapat digunakan untuk soal-soal lainnya. Dengan demikian, maka perlu adanya perbaikan dalam proses pembelajaran yang menerapkan masalah sebagai awal pembelajaran guna siswa dapat membangun pengetahuannya. Sebuah pembelajaran yang menantang dan memberikan kesempatan pada siswa untuk belajar mengkontruksi pengetahuannya. Arends (dalam Panjaitan dan Sri, 2017) menyeleksi beberapa model pengajaran yang sering dan praktis digunakan guru dalam mengajar, yaitu: presentasi, pengajaran langsung, pengajaran konsep, pembelajaran kooperatif, pembelajaran berdasarkan masalah, dan diskusi kelas.

Cara siswa merepresentasikan dan memecahkan masalah matematika merupakan faktor yang sangat penting bagi perkembangan kognitif siswa dan mempengaruhi hasil belajar matematika siswa. (Pardede, 2017). Salah satu cara yang dapat membuat peserta didik aktif dalam proses pembelajaran adalah dengan menerapkan model pembelajaran yang bervariasi Sebagai pendidik, guru perlu memilih model yang tepat untuk menyampaikan sebuah konsep kepada anak didiknya. Pemecahan masalah merupakan bagian dari strategi belajar mengajar yang sangat penting terutama dalam kegiatan belajar mengajar matematika. (Kadir,2016). Dari berbagai model pembelajaran guru harus dapat menciptakan suasana belajar yang menyenangkan sehingga dapat menumbuhkan minat peserta didik dalam mengikuti pembelajaran. (Park,2015).

Melihat permasalahan tersebut, perlu dilakukan perbaikan agar proses pembelajaran menjadi lebih baik sehingga dapat meningkatkan kualitas pembelajaran. Dari berbagai model pembelajaran guru harus dapat menciptakan suasana belajar yang menyenangkan sehingga dapat menumbuhkan minat peserta didik dalam mengikuti pembelajaran.

\section{METODE}

Penelitian ini menggunakan studi dokumen atas hasil-hasil penelitian sebelumnya. Pengumpulan data dalam penelitian ini dilakukan dengan menelusuri jurnal pada beberapa media elektronik seperti digital library, internet, maupun koleksi jurnal perpustakaan. Penelusuran jurnal dilakukan melalui Google Cendekia. Kata kunci yang digunakan untuk penelusuran jurnal adalah: kemampuan pemecahan masalah, model. 
Dari hasil penelusuran yang diperoleh, dipilih yang memenuhi kriteria yaitu tersedianya data tentang penerapan suatu model pembelajaran yang dapat mempengaruhi kemampuan pemecahan masalah matematika siswa. Dari beberapa model pembelajaran dipilih tiga hasil penelitian untuk dianalisis lebih lanjut. Analisis menggunakan metode pembandingan untuk menentukan dampak penerapan beberapa model pembelajaran terhadap kemampuan pemecahan masalah matematika siswa.

\section{HASIL DAN PENELITIAN}

Setelah melakukan browsing pada google cendekia, diperoleh hasil penelitian seperti berikut ini. Dengan kata kunci kemampuan pemecahan masalah, model. Dari hasil beberapa penelusuran diperoleh tiga penelitian yang dipilih: Nur Alfi Qamardhani, Edy Surya (2017), Fika Indah Perawansa, Edy (2017), Lela Anggraini, Rusdy A. Siroj dan Ratu Ilma Indra Putri (2010). Bendasarkan hasil browsing yg dilakukan menggunakan Google Cendekia terseleksi seperti di atas, hasil analisis terkait beberapa model pembelajaran dalam meningkatkan kemampuan pemecahan masalah matematika disajikan berikut ini.

\section{Tabel 1. Besarnya Pengaruh Beberapa Model Pembelajaran Terhadap Kemampuan} Pemecahan Masalah Matematika Siswa

Peningkatan Hasil Belajar

\begin{tabular}{|c|c|c|c|c|c|}
\hline No & Judul & Peneliti & Semula & Sesudah & Gain $(\%$ \\
\hline & $\begin{array}{l}\text { Efektivitas Penggunaan } \text { Metode } \\
\text { Guided Discovery Dalam } \\
\text { Meningkatkan Kemampuan } \\
\text { Pemecahan Masalah Matematika }\end{array}$ & $\begin{array}{l}\text { Nur A.Q, \& Edy } \\
\text { S. (2017), }\end{array}$ & $90 \%$ & $95 \%$ & $5 \%$ \\
\hline & \begin{tabular}{lrr} 
Upaya & \multicolumn{2}{r}{ Meningkatkan } \\
Kemampuan & \multicolumn{2}{c}{ Pemecahan } \\
Masalah Melalui & Model \\
Pembelajaran & Means-Ends \\
Analysis Pada & Siswa & Mts \\
Aisyiyah Sumatera & Utara & T.P \\
$2016 / 2017$ & &
\end{tabular} & $\begin{array}{l}\text { Fika I.P, \& Edy } \\
\text { S. (2017), }\end{array}$ & $38 \%$ & $93.1 \%$ & $55.1 \%$ \\
\hline 3 & $\begin{array}{l}\text { Penerapan Model Pembelajaran } \\
\text { Investigasi Kelompok Untuk } \\
\text { Meningkatkan Kemampuan } \\
\text { Pemecahan Masalah Matematika } \\
\text { Siswa Kelas VIII-4 SMP N } 27 \\
\text { Palembang }\end{array}$ & $\begin{array}{l}\text { Lela Anggraini, } \\
\text { Rusdy A. Siroj } \\
\text { dan Ratu Ilma } \\
\text { Indra Putri } \\
(2010)\end{array}$ & $60 \%$ & $89 \%$ & $19 \%$ \\
\hline
\end{tabular}

$\begin{array}{lrrr}\text { Rata-rata Hasil Belajar Siswa } & 62,66 & 92,33 & 26,36\end{array}$

Data yang diperoleh dalam penelitian ini bahwa pembelajaran dengan tiga model yang berbeda terhadap kemampuan pemecahan masalah matematika siswa dapat meningkatkan hasil belajar matematika peserta didik. Peningkatan hasil belajar dari yang terendah $5 \%$ sampai yang tertinggi $55,1 \%$, dengan rata-rata 26,36\%. Rata-rata hasil 
belajar peserta didik sebelum penelitian tindakan kelas adalah 62,66 dan setelah dilakukan penelitian tindakan kelas dengan penerapan model terjadi peningkatan menjadi 92,33 . Seperti yang tersaji pada tabel di atas, penerapan dari ketiga model yang berbeda pada pelajaran matematika dapat meningkatkan hasil belajar peserta didik.

Melalui pemecahan masalah siswa - siswa dapa berlatih dan mengintegrasikan konsep - konsep, teorema - teorema dan keterampilan yang telah dipelajariec. Dengan menggunakan pemecahan masalah dalam matematika, siswa mengenal cara berfikir, kebiasaan untuk tekun, dan keingintahuan yang tinggi, serta percaya diri dalam situasi yang tidak biasa, yang akan melayani mereka secara baik diluar kelas matematika. Dalam kehidupan sehari - hari dan ditempat kerjakan menjadi pemecah masalah yang baik dan dapat mengarah menjadi hal yang menguntungkan. (Surya).

Menurut Eviyanti, dkk (dalam Surya, 2017) bahwa secara umum, pembelajaran berbasis masalah adalah model pembelajaran yang menggunakan masalah dunia nyata sebagai konteks bagi siswa untuk belajar tentang berpikir dan keterampilan pemecahan masalah kritis, serta untuk memperoleh pengetahuan dan konsep yang esensial dari materi pembelajaran. Eviyanti, dkk(dalam Surya, 2017) mendefinisikan bahwa "model pembelajaran berbasis masalah dapat diartikan sebagai rangkaian kegiatan belajar, dengan penekanan pada proses penyelesaian masalah yang dihadapi secara ilmiah".

Hasil penelitian ini juga didukung oleh penelitian yang sebelumnya yang dilakukan oleh Anting (dalam Panjaitan dan Sri, 2017) di kelas VIII SMP Negeri 1 Badiri, menyatakan bahwa terdapat peningkatan pemecahan masalah. Nilai rata-rata kemampuan pemecahan masalah yang berjumlah 42 siswa pada tes diagnostik adalah $27,74 \%$. Setelah dilakukannya tes pada siklus I, nilai ratarata kemampuan pemecahan masalah meningkatkan menjadi 63,03 dengan tingkat ketuntasan klasikal 52,94\% dan setelah dilakukan siklus II, diperoleh rata-rata tes kemampuan pemecahan masalah siswa menjadi 32,45 dengan ketuntasan klasikal 85,29\%.

Keberhasilan proses pembelajaran tidak terlepas dari kemampuan guru menerapkan model-model pembelajaran yang berorientasi pada peningkatan intensitas keterlibatan siswa secara efektif di dalam proses pembelajaran. Pengembangan model pembelajaran yang tepat pada dasarnya bertujuan untuk menciptakan kondisi pembelajaran yang memungkinkan siswa dapat belajar secara aktif dan menyenangkan sehingga siswa dapat meraih hasil belajar dan prestasi yang optimal. (Anggraini, 2010).

Seperti yang tersaji pada tabel di atas data yang diperoleh menunjukkan bahwa dengan penerapan model pada masing-masing jurnal dapat diketahui bahwa terjadi peningkatkan kemampuan pemecahan masalah matematika yang ditandai dari peningkatan hasil belajar siswa.

\section{KESIMPULAN}

Pembelajaran matematika yang dilakukan guru di sekolah pada umumnya masih belum berjalan secara maksimal. Guru dalam proses pembelajaran masih sering menggunakan metode ceramah untuk menyampaikan materi. Sedangkan materi dalam matematika adalah konsep yang bersifat abstrak. Proses pembelajaran masih berpusat pada guru (teacher centered). Akibatnya matematika dianggap sebagai salah satu mata pelajaran yang sulit dan capaian hasil belajar siswa kurang maksimal.

Pemilihan model pembelajaran yang tepat adalah salah satu cara untuk mengoptimalkan proses dan hasil belajar peserta didik. Melalui pemecahan masalah siswa dapat berlatih mengintegrasikan kosep-konsep, teorema-teorema. Dari beberapa jurnal yang telah dianalisis, dengan penerapan model pada pembelajaran matematika dapat diketahui bahwa terjadi peningkatkan kemampuan pemecahan masalah matematika yang ditandai dari peningkatan hasil belajar siswa.

\section{DAFTAR PUSTAKA}

Abubakar, B.A., and Mohammad Y.A. 2015. "Self-Directed Learning and Abilitys of 
Problem Based Learning: A Case of Nigerian Secondary Schools Chemistry Students," International Education Studies, 8 (12). 70-78.

Anggraini L., Ratu I.,I.,P., dan Rusdy A. S. 2010. Penerapan Model Pembelajaran Investigasi Kelompok Untuk Meningkatkan Kemampuan Pemecahan Masalah Matematika Siswa Kelas Viii-4 Smp Negeri 27 Palembang. Jurnal Pendidikan Matematika. 4(1), 34.

Becerra-Labra, C., Gras-Marti, A., \& Torregrosa, MJ. 2012. Effects of a Problem-based Structure of Contents on Conceptual Physics Learning and the Ability to Solve Problems. International Journal of Science Education, 34 ( 8), 1235-1253. doi: 10.1080 / 09500693.2011.619210

Dwi, I.M., Arif, H., and Sentot, K. 2013. "Effect of Problem Based Learning Model to Understanding Concepts and Problem Solving Abilitys," Jurnal Pendidikan Fisika Indonesia, 8-17.

Hajidin, Rahmah., J dan Suci M., S. 2016. Pengembangan Perangkat Problem Based Learning (PBL) dalam Pembelajaran Matematika di SMA. Jurnal Didaktik Matematika. 3(2), 43

Heller, P., Ronald, K. and Scott, A., "Teaching Problem Solving Trough Cooperative Grouping," American Assosiation of Physics Teachers, 60 (7). 627-636. 1992.

Kadir, Z.,A.2016. "Does Problem-Based Learning Improve Problem Solving Ability?-A Study among Business Undergraduates at Malaysian Premier Technical University," International Education Studies, 9 (5). 166

NCTM. 2000. Principles and Standards for School Mathematics. NCTM: Reston VA.

NCTM (National Council of Teachers of Mathematics). 2000. Principles and Standards for School Mathematics. Reston. VA : NCTM

Montague, M. 2007. Math Problem Solving for Middle School Students with Disabilities. Available : http://www.k8accesssenter.or g/training

Panjaitan M, Sri R., Rajagukguk, 2017. Upaya Meningkatkan Kemampuan Pemecahan Masalah Matematika Siswa dengan Menggunakan Model Pembelajaran Problem Based Learning di Kelas X SMA. Jurnal Inspiratif, 3(2).

Pardede A., I., Asmin, Dan Edy Surya. 2017. Perbedaan Kemampuan Representasi Dan Pemecahan Masalah Matematika Siswa Dengan Pendekatan Matematika Realistik Dan Pembelajaran Biasa Di Smk Swasta Tamansiswa Medan. Paradikma. 10(1), 3

Park, S.J., and Sun-hee Choi. 2015. "Effects of Problem Based Learning on the Learning Attitudes, Critical Thinking Disposition and Problem Solving Abilitys of Nursing Students: Infant Care," Advanced Science and Technology Letters, 10(3). 192196.

Pehkonen, E. 2007. "Problem solving in mathematics education in Finland ". Finlandia: University of Helsinki.

Surya, E. dan Nur A., Q. 2017. Efektivitas Penggunaan Metode Guided Discovery Dalam Meningkatkan Kemampuan Pemecahan Masalah Matematika. Jurnal Kepustakaan. https://www.researchgate.net/publication/321832499.

Surya E. dan Novalina, R. 2017. Pengaruh Problem Based Learning (PBL) Terhadap Kemampuan Pemecahan Masalah Matematika Siswa SMP. JurnalKepustakaan. https://www.researchgate.net/pu blication/320322613.

Surya E. dan Fika I.,P. Upaya Meningkatkan Kemampuan Pemecahan Masalah Melalui Model Pembelajaran Means-Ends Analysis Pada Siswa Mts Aisyiyah Sumatera Utara T.P 2016/2017.

Surya E. dan Fika I., P. Upaya Meningkatkan Kemampuan Pemecahan Masalah Melalui Model Pembelajaran Means-Ends Analysis Pada Siswa Mts Aisyiyah Sumatera Utara T.P 2016/2017. Mahasiswa PPS Jurusan Pendidikan Matematika, UNIMED.

Surya E. dan Elvira R., H. 2017. Kemampuan Pemecahan Masalah Matematis Siswa 
Kelas Vii Dalam Menyelesaikan Persamaan Linear Satu Variabel. Semnastika Unimed. ISBN:978-602-17980-9-6.

Surya E. dan Rosmawaty S. 2017. Pengaruh Problem Based Learning (PBL) Terhadap Kemampuan Penalaran Matematis Siswa. Jurnal Kepustakaan. https://www.researchgate.net/publication/320402503. 2. 